Poznańskie Studia Teologiczne 28(2014), s. 99-113.

doi: $10.14746 /$ pst.2014.28.6

\author{
Joseph Ellul \\ University of Malta \\ Msida
}

\title{
Human identity and purpose according to the Qur'ân
}

Because the whole of existence is unified and issues from one Will, because humankind is a part of the universe that cooperates and acts in harmony with the other parts and because individual humans are cells which cooperate and act in harmony with the universe, there must be cooperation and harmony among them... Human life will not be rightly ordered until this cooperation and harmony are fully instituted in accordance with the program and law of God. ${ }^{1}$

Given that Islam as a religion is centred upon the oneness of God, most people might arrive at the mistaken conclusion that it has little or no room for a thorough consideration of humanity and its purpose. In actual fact, divine oneness in Islam lies at the heart of all discourse on human identity and purpose. What I propose in this article is to offer some insights into the relationship in Islam between God and humanity and, consequently, humanity's status in the created world. This would imply a twofold analysis that will deal with the question of human identity in relation to God and human identity in relation to the created world. Many times these two concepts cross each other's paths.

\section{"In the beginning, God..."}

Qur'ânic anthropological discourse is set within the context of the creation of the cosmos as a sign of divine oneness, omnipotence and providence. The Qur'ân offers a stark warning against those forgetting the sublime truth that nothing in the universe could be explained outside the divine realm. Nature carries the imprint of God who sets his seal on his work just as an artisan places his seal on the finished product of his craftsmanship. The Qur'ân may be considered as the key that deciphers what God has communicated to us concerning his will in the book of nature. In this perspective it is important to note that the Qur'ân does

${ }^{1}$ William E. Shepard, Sayyid Qub and Islamic Activism: A Translation and Critical Analysis of Social Justice in Islam, Leiden 1996, p. 29. 
not portray who God is but rather what God wills. The Qur'ân constantly draws its readers' attention to the divine presence in the cosmos and especially its influence upon the life of each and every human being.

\section{God's majesty and Man's obedience}

By contemplating creation Man is called upon to turn towards God and submit to him. This is humanity's sole vocation. This call $\left(d a^{c} w a\right)$ is dramatically portrayed in Q. 7:172-173 wherein God is depicted first and foremost as Lord of all creation who demands that the entire cosmos, and human beings in particular, acknowledge his lordship:

Remember when your Lord took away from Adam's children the seeds from their loins, and made them witness upon themselves: 'Am I not your Lord?' They answered: 'Yes, we witness' - lest you should claim on the Day of Resurrection: 'We were unaware of this.' Or else you might claim: 'But our ancestors too were once guilty of polytheism, and we were merely their later sed. Will you therefore destroy us because of the works of falsifiers?' Thus do we clarify Our revelations; perhaps they will turn back. $^{2}$

The above-quoted text refers to what is known by Muslims as the primordial pact or covenant (mît $\bar{a} q)$. Lying at the centre of this dramatic event that allegedly took place at the dawn of time is the assertion that only God is the Lord and the Master of all humanity. This includes his being recognized as creator, as the only one who has the right to be worshipped, and as the one who provides all things. The text therefore concludes that on the Day of Reckoning nobody will be excused for failing to give recognition to this truth while living on this earth. The stipulation of the pact is clear and straightforward thereby implying that whosoever fails to abide by it is fully responsible for his/her actions.

Man, in the final analysis, has the possibility of bearing witness to and proclaiming the oneness of God both by word and by his very existence. The proclamation of divine unicity is inscribed at the core of fundamental human nature.

The initial pact also carries a warning of the dire consequences that would follow upon those who fail to give God due recognition of his oneness by proclaiming the Muslim creed in its entirety. This is confirmed by those texts of the Qur'ân referring to the criteria applied on the Day of Judgement. ${ }^{3}$ The question posed in the latter part of the text above refers to those who fall into disbelief after having committed themselves to abide by the primordial pact.

\footnotetext{
${ }^{2}$ Unless otherwise stated, all passages from the Qur'ân are taken from The Qur'an: A New Translation, by Tarif Khalidi, London 2008.

${ }^{3}$ See, for instance, Q. 3:106; 18:103-105; 25:25-26; 75:22-25.
} 
The Qur'ân makes it abundantly clear that God's authority is manifest, and Man is duty-bound to accord recognition to this truth: God is the Lord of the world, including the entire human race, and demands obedience from every creature, including humanity. Every human being owes him obedience.

\section{Islam as the natural religion of humanity}

The above-mentioned primordial pact implies that Islam is intrinsic to human nature and that its denial or refusal is a denial and refusal of what it means to be human. Such a concept takes its cue from another fundamental anthropological text which affirms that God also demands of humanity that it follows the religion inscribed in its nature, which is that of the oneness of God, who sustains in harmony the whole of creation and who is enduring and immutable:

So set your face to the true religion, in pristine faith. This is the primordial nature that God implanted in mankind - there can be no change in God's creation. This is the religion unswerving, but most people know it not.

(Q. 30:30)

The first problem that arises with the consideration of this text regards the interpretation of the term fitra, translated above as "primordial nature". The English rendering of the term is correct, but it requires explanation. As Jacques Jomier" correctly argues, the term fitra does indeed mean "primordial nature" but this has to be necessarily qualified. It refers to primordial nature inasmuch as it is created by God, stamped with the seal of its creator and wholly directed towards him. It refers to nature as seen through the eyes of the believer. Seeing nature in this way directs the Muslim towards God. ${ }^{5}$ There is no notion here of creation as Man's dominion, as the object of human domination and exploitation as with the case of the first creation narrative in the Book of Genesis. Man tills the earth and enjoys its fruits but is well aware that God is its Lord and Master ${ }^{6}$.

The term fitra is above all that innate acknowledgement that God exercises divine power over all the cosmic forces as well as over the natural order of the world. The Lord $(a l-R a b b)$ who possesses such power is the creator of all that

${ }^{4}$ Jacques Jomier (1914-2008) was a Dominican priest and scholar of Islam. He was also one of the founders of the Institut Dominicains d'Études Orientales in Cairo and an active member of the institute for more than forty years. He taught in Cairo, Mawșil, and Ibadan. He was also a member of the Institut Catholique de Toulouse and Consultor to the Pontifical Council for Interreligious Dialogue.

${ }^{5}$ Jacques Jomier, Dieu et l'homme dans le Coran, Paris 1996, p. 35.

${ }^{6}$ This notion is in stark contrast to the creation account of Gn. 1:28 wherein it is stated:

God blessed them, saying to them, 'Be fruitful, multiply, fill the earth and subdue it. Be masters of the fish of the sea, the birds of heaven and all the living creatures that move on earth. 
lies in the heavens and on earth. For the Muslim worship according to nature consists in turning instinctively towards the invisible Lord in times of trial when one experiences helplessness, as well as when one is upholding what is good or warding off evil. The Muslim finds great assurance in achieving this purpose believing that he/she is the holder of the truth and that his/her infallible community prescribes by commanding the good and the proscribing evil:

You are the best community ever brought forth among mankind, commanding virtue and forbidding vice, and believing in God.

(Q. 3:110)

Sayyid Qutb ${ }^{7}$ believes that Islam, the cosmos and human nature are inextricably bound while at the same time he affirms that Islam is founded on the original nature according to which God created man:

The Islamic system is based on two fundamental ideas derived from its over-all conception of Divinity, of the universe, life and man: the idea of the unity of humanity in race, nature and origin, and the idea that Islam is the general world-wide system and that God accepts no other system because He accepts no other religion than Islam, and religion - in the Islamic understanding - is the general system that governs life. ${ }^{8}$

This is perhaps the only religious doctrine ('aqīda) that enjoys unanimity within the world of Islamic scholarship. On the other hand, those to whom the Qur'ân refers as 'associators', who adore many gods (al-mušrikūn), follow their personal passions and their various tendencies, which will lead them to split up into several sects and parties. The upright, on the contrary, are totally absorbed with accepting Islam while the hearts of those who have deviated from its path no longer have any proof or guide. Islam forges a link between the nature of the universe and that of humanity. God who created human nature has also established Islam. Consequently, no doubt, no hesitation is allowed to crop up in the conscience of the Muslim since the detailed prescriptions found in the Qur'ân trace the right path (al-șirāt al-mustaqìm) ${ }^{9}$ and also allow him/her to instill order in the relations between Man and nature. Crises of conscience and the anxiety of

\footnotetext{
${ }^{7}$ Ibrāhīm Ḥusayn Šādilī Sayyid Quṭb (1906-1966) was an Egyptian writer and prominent activist of the Muslim Brotherhood. Today he is considered to be one of the forerunners of the current resurgence of radical Islam. He took an active part in the revolution that brought Gamāl 'Abd al-Nāșir to power in 1952, but eventually fell out with the regime accusing it and other Arab nationalist governments of being anti-Islamic. He was tried, condemned and imprisoned several times for his radical ideas. He was executed in 1966. Apart from the work mentioned in n. 1, his principal ideas are to be found in several works and articles written during the 1940's and 1950's, and particularly in his commentary on the Qur'ân, Fīzilāl al-Qur'ân (In the Shade of the Qur'ân), which he wrote during one of his periods of imprisonment.

${ }^{8}$ William E. Shepard, Sayyid Qutb and Islamic Activism, op.cit., p. 109.

${ }^{9}$ Q. 1:6.
} 
seeking are totally alien to Muslim belief and practice. In the improbable scenario that doubt might plague his/her peace of mind, the community is there present to re-establish order and sanction any transgression, even though it is also ready to welcome back in its fold those who repent. Sayyid Quṭb goes so far as to affirm that the use of force is legitimate in order to achieve this end:

Because the whole of existence is unified and issues from one Will, because humankind is a part of the universe that cooperates and acts in harmony with the other parts and because individual humans are cells which cooperate and act in harmony with the universe, there must be cooperation and harmony among them. Therefore, Islam's conception makes humanity a unity, whose parts separate in order to come together again, differ in order to harmonize, and hold various opinions so that they may finally cooperate with each other, in order that humanity may become fit to cooperate with the whole unified existence... Human life will not be rightly ordered until this cooperation and harmony are fully instituted in accordance with the program and law of God. This must be accomplished for the welfare of humanity as a whole. Therefore it is even permissible to use force to bring those who stray back to the right path. ${ }^{10}$

The Qur'ân consistently drives home the message that God is Lord of the universe. He bestows his munificence upon humanity. Man seeks guidance and help from the One God, who alone is to be worshipped. In the words of Seyyed Hossein Nassr, ${ }^{11}$ "every manifestation of human existence should be organically related to the first part of the Šahāda, La ilāha ill' Allahu, which is the most universal way of expressing unity." 12 The profession of faith in the uniqueness of God and the consequent affirmation of Muhammad as his servant and messenger, the greatest and the seal of previous revelations (Jewish and Christian), guarantee the Muslim's status in the present as well as in the afterlife.

For the Muslim humanity takes its meaning, and expresses its consistency and its status before God and for God. For this reason all social life in Islam must carry traces of the divine presence and enforce God's calls and his demands. These are expressed by way of three fundamental elements in the life of the ordinary Muslim:

a. Minarets - from which the voice of the mu'addin calls the Muslim to prayer five times a day.

b. Qur'ânic inscriptions in public places - such as schools, government buildings and hospitals.

c. Great communal celebrations - Ramadāan, Hăğğ, Mīlād al-Nabī, and other public manifestations of collective faith.

${ }^{10}$ William E. Shepard, Sayyid Qub and Islamic Activism, op.cit., p. 29.

${ }^{11}$ Seyyed Hossein Nașr is an Iranian scholar and author of numerous works on Islamic thought and spirituality.

${ }^{12}$ Seyyed Hossein Nașr, Ideals and Realities of Islam, London 1966, p. 29. 
The fulfillment of the Muslim's earthly life takes place during the pilgrimage ( $h a \breve{g} \breve{g}$ ) to Makka, which gathers more than a million Muslims. The crowning moment of this event is solemnized by the assembly of all the pilgrims in the plain of 'Arāfât for evening prayer on the eve of the commemoration of the sacrifice of Abraham (' $\bar{l} d$ al-adh $\bar{a}$ ). Here the community becomes fully aware of its cohesive force, of its unity in the universality of peoples, of its overwhelming force in the confession and worship of the One God: Allāh.

\section{The role of humanity in the created world}

The Qur'ân proclaims first and foremost that the entire cosmos is created. In this way it also situates Man before God's presence in order to make him conscious of his true status. All human activity is inscribed within the framework of creation. The Qur'ân constantly reminds Man of his natural duty to proclaim God as creator.

One does not find in the Qur'ân a detailed account of how creation came into being such as is found in the Bible. The creation of the cosmos is referred to several times in the sacred book of Islam, but the texts are rather brief and are intended to drive home a particular message: the subject is always God and the lesson to be learned is that humanity should realize before whom it stands. No human activity goes unobserved or unaccounted for. The following passage is but one example:

He it is Who created the heavens and earth in six days, then sat firmly on the throne.

He knows whatever passes into the earth and whatever comes out thereof,

What comes down from heaven, and what ascends thereto;

He is with you wherever you may be; He knows full well what you do.

(Q. 57:4) $)^{13}$

The Qur'ân also speaks of Man's status and role in relation to the created world. The following is the text which best portrays this situation:

It is He Who hath created for you all things that are on earth; Moreover His design comprehended the heavens, for He gave order and perfection to the seven firmaments; and of all things He hath perfect knowledge.

Behold, thy Lord said to the angels: "I will create a vicegerent ( $\underline{h} a l i \bar{f} a)$ on earth." They said: "Wilt Thou place therein one who will make mischief therein and shed blood? - whilst we do celebrate Thy praises and glorify Thy holy (name)?" He said: "I know what ye know not."

(Q. 2:29-30) ${ }^{14}$

${ }^{13}$ See also Q. 2:255, the so-called Verse of the Throne.

${ }^{14}$ In spite of the archaic nature of the language used I have opted in favour of this translation by 'Abdallah Yūsuf 'Alī because of the use of the term vicegerent as the English equivalent of the 
Here again, reference to creation is intended to articulate Man's standing before God in the created world. Adam is indeed the vicegerent of God on earth, but he is also fully aware that all that he possesses is a gift from God. God was alone at the moment of creation. Although in the text itself the audience appears to be made up of angels, the audience to whom this dialogue is aimed is much wider. It is addressed to all of humanity. ${ }^{15}$

According to the Persian commentator al-Zamahšari ${ }^{-16}$ the term halïfa means 'one who substitutes for another'. In the context of v. 30 he offers two interpretations, the first being substitute from among the angels since they were the inhabitants of the earth. In this understanding Adam and his offspring took their place. Here Zamahšsarī mentions a variant reading for $\underline{h} a l i \bar{f} a$, namely $\underline{h} a l i \bar{q} a$ meaning 'creature'. The second interpretation is that of a vicegerent of God, because Adam was the vicegerent of God on earth. ${ }^{17}$ In the same way so is every prophet. In order to prove his point he cites Q. 38:26, which refers to David with the same title:

O David! We did indeed make thee a vicegerent on earth: so judge thou between men in truth (and justice): Nor follow thou the lusts (of thy heart), for they will mislead thee from the Path of Allah. For those who wander astray from the Path of Allah, is a Penalty Grievous, for that they forget the Day of Account. ${ }^{18}$

In this text Zamahšarī interprets the term as vicegerent over the dominions of the earth, as some sultans used to appoint someone over certain countries to rule over them. God's command in the second part of the verse, "so judge thou between men in truth (and justice)" is a consequence of holding such a high office. David was to judge by the rule of God since he was his vicegerent. ${ }^{19}$

With reference to Adam Zamahšarī affirms that, even though God was well and truly capable of deciding for himself, he took council with the angels. His intention met with astonishment on their part. Adam and his offspring are regarded as people of disobedience whereas the angels consider themselves as the peo-

Arabic $\underline{h} a l i \bar{f} a$ which is more appropriate in this context. Yūsuf 'Alī's interpretation is still widely recognized as one of the most accurate.

${ }^{15}$ Jacques Jomier, Dieu et l'homme dans le Coran, op.cit., p. 41.

${ }^{16}$ Abū 'l-Qāșim Mạ̣mūd b. 'Umar al-Zamahššrī (67/1075-538/1144) is best known as a scholar of Arabic, a theologian and a philologist. As a theologian he followed the teachings of the Mu'tazila School, which championed the use of reason in order to expound the teachings of the Qur'ân and taught that the Qur'ân, as the word of God in its external manifestation, was created. In spite of this bold assertion, his works were widely read in orthodox circles. In his commentary on the Qur'ân, al-Kaššăf'an ḩaqū'iq gawämid al-Tanzīl, he gives particular attention to the lexicographical aspect of the sacred text, explaining it by making use of ample extracts from old poetry.

17 Al-Zamaȟšarī, al-Kaššăf ' an haqā̄'iq gawāmid al-Tanzīl (Miṣr: Al-Maktaba al-Tiğāriyya al-kubra, 1307 A.H.), $1^{\text {st }}$ ed., vol. I, p. 51 f.

${ }^{18}$ Like the previous quote, this one has been taken from 'Abdallah Yūsuf 'Alî's translation.

${ }^{19}$ See al-Zamašarī, al-Kaššā $f$, (2nd ed.), 1373, vol. IV, p. 69. 
ple of obedience. This appears to be in contradiction to the fact that God 'does nothing but good'20. However God knows that which is hidden knowledge for the angels and this is reason enough for them not to persist in arguing about his decision.

Another renowned commentator of the Qur'ân, Faḥr al-Dīn al-Rāzīi, ${ }^{21}$ in his Mafātīh al-Gayb (commonly known as al-Tafsìr al-Kabīr), begins his analysis of the text of Q. 2:30 by discussing whether God was speaking to all the angels or to some of them. He cites a hadīt taken from al-Daḥhāa ${ }^{22}$ which shows that the earth was previously inhabited by the ğinn who, however, wrought corruption and bloodshed. Consequently God sent Iblīs with an army of angels who slaughtered them and chased them out of the land. Whereupon God said to the angels: "I will create a vicegerent on earth." Al-Rāzī defines the term $\underline{\text { halì }} a$ as 'one who substitutes for another and takes his place', which is a more ample definition than that given by al-Zamahšarī. In order to prove his point al-Rāzī cites two verses from the Qur'ân wherein the term is used in the plural. ${ }^{23}$ Thus for him the term haliz $f a$ denotes a substitute and, at the same time, a successor. As to who is the one intended as vicegerent he offers two possibilities: (a) It is Adam who, either takes the place of the ginn or substitutes for God; or (b) it is the progeny of Adam because they succeed one another. He finally adds an explanation to the variant reading of $\underline{h} a l i \bar{f} f a$ is an expanded version of that of al-Zamaȟšarī. He states in fact that, since the term is both singular and plural in form, just as it is both masculine and feminine, one must read halìqa with $q \bar{a} f .{ }^{24}$

Another Muslim commentator of the classical period, Nāșir al-Dīn al-Bayḍāwi $\overline{1}^{25}$ considers this verse from another point of view. He states that God's

${ }^{20}$ Zamahšarī on Q. 2:30 in al-Kaššāf, vol. I, p. 51.

${ }^{21}$ Fah̆r al-Dīn Abū 'Abd Allah Muḥammad b. 'Umar al-Rāzī (543/1149-606/1209) was a renowned theologian and philosopher who belonged to the Aš ariyya School. He is best known for his monumental commentary on the Qur'ân Mafätīh al-Gayb (The Keys of that which is hidden) known appropriately by the title Al-Tafsìr al-Kabìr (The Great Commentary) which runs to 32 volumes. This work is considered not only to be an Aš́arite answer to the Mu'tazili commentary of al-Zamahšarī, but also provides the author with an excellent means for exposing his philosophical views.

${ }^{22}$ Al-Dahhāk b. Muzāhim (d. 105/723 or 106/724) was a distinguished exegete, traditionist and grammarian who had a madrasa (school) in Kūfa.

${ }^{23}$ Q. 10:14; 7:74.

${ }^{24}$ Faḥr al-Dīn al-Rāzī, al-Tafsīr al-Kabīr (Mișr: Al-Maba'a al-Mișriyya, 1352/1933) vol. I, pp. 159-174.

${ }^{25}$ Nāṣir al-Dīn Abū 'l-ayr 'Abd Allāh b. Muhammad b. 'Alī al-Bayḍāwī (d. 685/1286) - a scholar belonging to the Šăfi ${ }^{`} \overline{1}$ School of Law who occupied the post of Qāḍi in Širāz. He had a reputation for wide learning and wrote on a number of subjects including tafsir fiqh, and i $i^{i} \bar{a} b$. His great merit lies not in the originality of his works but, rather in his ability to absorb and synthesize in his writings the ideas of other authors. He is also noted for the brevity with which he treats various subjects. 
favour towards all people is threefold: (a) by way of the creation of Adam; (b) by way of his ennoblement; (c) by way of his being set above the angels when God ordered them to worship him (Q. 2:34). His definition of the term halifa runs parallel to those of al-Zamaȟšarī and al-Rāzī adding that it also means acting on one's behalf. He also mentions the possibility of the variant reading of haliqqa with $q \bar{a} f$. The innovation which al-Bayḍāwi introduces in his commentary entitled Anwār al-tanzīl wa așrār al-ta'wīl concerning this verse is his philosophical study on Man's faculties based on the Aristotelian ordering of the will to the intellect in the exercise of moral virtues. He takes this position in order to arrive at the reason why Adam was appointed vicegerent. Al-Bayḍāwī distinguishes three faculties in Man: the concupiscible and the irascible, which lead him to corruption and bloodshed, and the intellective faculty, which calls him to knowledge and obedience. The angels, he says, objected to God's decision because they considered them as separate entities in Man. However, the harmonious combination of these faculties brings out the necessary qualities which make Man's appointment as vicegerent appropriate. ${ }^{26}$

God further demonstrates the wisdom of his choice by teaching Adam the names of every living creature, something which according to the Qur'ân was concealed from the angels:

He taught Adam the names of all things. Then He displayed them to the angels and said: 'Tell me the names of these things, if you are truthful'

They said: 'Glory be to You! We have no knowledge except what You taught us. You! You are All-Knowing, All-Wise.'

God said: 'O Adam, reveal to them their names.' When Adam revealed their names, God said: 'Did I not tell you that I know the Unseen of the heavens and the earth? That I know what you make public and what you hide?'

(Q. 2:31-33)

These verses form an interesting parallel with the Biblical account of creation as found in the Book of Genesis, wherein it is narrated that God brought the creatures before Adam and it was Adam who gave them their names. According to the creation narrative found in the first chapter of Genesis God creates by naming. Giving a name implies possession of the object or creature designated. In the case of the creation narrative in the second chapter of the Book of Genesis Man is appointed by God as co-creator at the moment when he gives every living creature its name. Co-creation and stewardship of the created world on the part of Man are two sides of the same cosmic reality. ${ }^{27}$ The Qur'ân, however,

${ }^{26}$ Al-Bayḍāwī, Anwār al-tanzīl wa aṣrār al-ta'wīl, (Muștafā al Bābī 1-Halabī wa awlāduhu, 1344 AH.), pp. 34-36.

${ }^{27}$ There are instances in the Bible where God is said to give names to what he has created. Psalm 147:4, for example, states: "He determines the number of the stars, he gives to all of them 
would consider the notion of man as co-creator ( $\underline{\text { Ha }}$ liq) as širk (associating other beings with God's sole and unique divinity). In agreement with biblical thought God remains firmly in possession of the world that he created ${ }^{28}$ but, contrary to the biblical narratives, Man in no way participates and is by no means involved in God's creative actions. In the Qur'ân the subject of the verb 'to create' (halaqa) is always God. Some Muslim scholars, especially those among the Mu'tazila ${ }^{29}$ go only as far as stating that man is $F \bar{a}^{c} i l$ (agent). Furthermore, God possesses everything precisely because only $\mathrm{He}$ is creator:

Or is it that they were created from nothing?

Or could it be that they are creators?

Or was it them who created the heavens and the earth?

Rather, they possess no certainty.

Or is it that they possess the treasures from your Lord?

Or are they the ones in supreme control?

(Q. 52:35-37)

This passage is very reminiscent of God's interrogation of Job, in which human nature is faced with its limitations as well as with its folly in seeking to exercise divine power as creator and divine providence in sustaining the cosmos. ${ }^{30}$ In it lies the essence of a natural theology that teaches the Muslim the undeniable truth regarding the human situation before God. It drives home the lesson concerning human identity and presence in the natural world laying emphasis on the reality that each and every human being belongs to God and is dependent upon him.

Man is responsible to God for his actions in the created world. The Qur'ân makes it absolutely clear that Man was nothing and that he was created: "But does man not remember that We created him beforehand, when he was nothing?" (Q. 19:67). Only God creates; the false deities and beings associated with God are not capable of anything $;{ }^{31}$ they are nothing.

their names." The context here, however is that the whole cosmos testifies to God's wisdom and omnipotence. See also Prov. 30:4.

${ }^{28}$ See Ps. 50:12b ("the world and all that is in it is mine"); Q. 53:31 ("And to Allah belongs whatever is in the heavens and on the earth").

${ }^{29}$ The Mu'tazila was a theological school that flourished between the $8^{\text {th }}$ and the $10^{\text {th }}$ centuries. Its centres were in the cities of Bașra and Baghdad (both in present-day Iraq). Its foundation is attributed to Wāṣil b. 'Ațā' (d. 748). The principal doctrines of this school concern the oneness of God and its corollary, the created-ness of the Qur'ân, and divine justice. They also applied reasoned opinion in the interpretation of the Qur'ân. They were also heavily criticized by their detractors (the school of the Ašariyya) for their strict identification of divine essence and attributes as well as their emphasis on divine justice to the detriment divine omnipotence.

${ }^{30}$ See Jb. 38-41. See also Prov. 30:1-4.

${ }^{31}$ Q. 22:73; 31:11. This is also a recurring theme in the Old Testament tradition. See, for example, Ps. 115:4-8; 135:15-18; Is. 44:9-10; Jer. 10:1-3; Bar. 6:3-8. 
The Qur'ân also reminds humanity of the way it came into being and the base material out of which it was fashioned lest it become proud and forgetful:

God it was who created you from dust, then from a sperm, then fashioned you into two genders. No female bears or delivers save by His knowledge; no person who attains old age shall attain it, nor will his life be curtailed, except it be in a Book a thing easy for God.

(Q. 35:11) $)^{32}$

The above quotation draws our attention to a few particular details. First of all, this passage is simply indicating the matter which goes into Man's makeup. Secondly, creation is extended also to sexual intercourse between a man and a woman; it continues with the development of the embryo within the maternal womb, and finally completes its cycle with birth, growth into maturity and subsequent decline. Also, marriage is portrayed as a natural calling common to all of humanity, both men and women. From the moment of creation both were called and enjoined to form a family. Therefore, marriage is both a human and a religious duty. In other words, the lesson to be learned from this verse is that the human being's entire life span lies within the all-encompassing creative act of God.

Like the world in which he lives, Man is also created and is perishable. Located at the heart of nature which submits to God, Man must imitate the cosmos in submitting to God. The Islam (submission) of human beings is inscribed within the framework of the Islam of the entire cosmos: "All who are upon it (i.e., the earth) shall perish, and there remains the face of your Lord, Majestic and Noble" (Q. 55:26-27). This sense of awe and adoration before God is given a voice by way of the expression Allāhu Akbar (God alone is great). ${ }^{33}$

The Qur'ânic portrayal of creation lies at the basis of the Muslim perception of one's personal life and its purpose. God is Lord and Man was created for no other reason but to worship God: "I created the Jinn and humans but to worship

\footnotetext{
${ }^{32}$ See also Q. 7:189; 14:4; 15:28 (in this case a strong term is applied to the matter with which Man is created, namely "moulded slime"); 25:54; 39:6; 55:14. A very similar notion is to be found in Ps. 139:13.16: "For you formed my inward parts, you knitted me together in my mother's womb... Your eyes beheld my unformed substance; in your book were written, every one of them, the days that were formed for me, when as yet there was none of them."

${ }_{33}$ Although this phrase is today identified with Islam, its roots are to be found in the Hebrew Biblical tradition. See, for instance, Ps. 40:16; 95:3; 96:4; 135:5; 145:3; 147:5; 2 Sam. 8:22; Jb. 36:26. It is worth noting that in his Arabic translation of the Psalms, undertaken with the collaboration of the Dominican Fathers of Cairo, Al-Șādiq Kāmil Husayn (brother of the renowned author of the novel Qarya Zālima [The City of Wrong] Muhammad Kāmil Husayn) translated the phrase 'God is Great' in the above-mentioned psalms as Allähu Akbar or fa 'l-yukabbiri llāha. See Samir Khalil Samir, Une Lecture de la foi chrétienne dans le context Arabo-Musulman, in Proche Orient Chrétien, „Tome” 42(1992), fasc. 1-2, pp. 57-125.
} 
Me" (Q. 51:56). As for the different aspects of human existence these serve as a test. ${ }^{34}$

The Qur'ân draws the attention of the Muslim to the perfection and to the order existing in nature as well as to the wisdom that rules over it. ${ }^{35}$ By means of creation nature reminds Man of the oneness of God and teaches him some of the divine attributes. In contrast with what one may conclude from the development of Old Testament cult and traditions, in the Qur'ân Man is portrayed from the beginning as a strict monotheist, that is to say, a believer in and a proclaimer of the existence of one God to the exclusion of any other being claiming divinity. The Qur'ân presents Islam as the primordial religion based on the oneness of God that began with Adam himself. Adam was a monotheist from the beginning. Humanity did not evolve gradually from polytheism to monotheism. On the contrary from time to time deviations occurred from the original monotheism as practiced by the first human beings. ${ }^{36}$ Humanity was thus originally monotheist of its very nature but gradually fell into polytheism and had to be reminded periodically of the original doctrine of monotheism by means of prophets and messengers sent by God. This is the story of all the great protagonists of the Qur'ân such as Abraham ${ }^{37}$ and Moses, ${ }^{38}$ who are Biblical characters, and to Hūd, ${ }^{39}$ S'âlih,,${ }^{40}$ and Šu $a y b$, who are Messengers sent specifically to Arabian tribes. ${ }^{41}$ Finally, it is also the story of Muhammad. Islam is, therefore, envisaged by the Qur'ân as both the primordial religion and the final religion perfected for humanity. It is the primordial religion because it is founded on the doctrine of the oneness of God, which has always existed and which all creation proclaims; it is the final religion because it is the religion to be accepted and followed, the Qur'ân being the final, perfect and definitive word of God handed down to Muhammad, the Seal of the Prophets ( history is not linear, as in Christianity, but pendular.

At first glance the created world causes one to draw some lessons concerning one's origins. Life consists of a series of dynamic processes, beginning with conception in the womb and ending with death. Throughout these stages the omnipotence of God is continuously stressed by the Qur'ân in order to underline

\footnotetext{
${ }^{34}$ See Q. 67:2.

${ }^{35}$ See Q. 67:3-4. Here again, the notion of the perfection, order and harmony in creation as indicative of the oneness of God is a common theme in the Wisdom literature of the Bible. See, for example, Wis. 13:1-9.

${ }^{36}$ Seyyed Hossein Nașr, Ideals and Realities of Islam, op.cit., p. 33.

${ }^{37}$ See Q. 6:75 ff; 19:41 ff.

${ }^{38}$ See especially Q. 7:103-167; 20:9-98.

${ }^{39}$ See Q. 7:65; 11:50 ff; 26:124 ff; 46:21.

${ }^{40}$ See Q. 7:73.7 5ff; 11:61 ff; 26:142 ff; 27:45 ff.

${ }^{41}$ See Q. 7:85 ff; 11:84 ff; 26:177 ff; 29:36 ff.
} 
the message that the one who bestowed life the first time is able to bestow it a second time on the Day of Resurrection.

Creation teaches that God is All-Powerful (Qadīr). ${ }^{42}$ This divine attribute, as with all the other attributes, is intimately linked with divine oneness. The good and evil that God wills to his creatures would reach them without their having any power to halt or change it:

If God touches you with harm, none but He can remove it,

And if $\mathrm{He}$ touches you with good, He is Omnipotent.

He is All-Powerful over His worshippers,

All-Wise, All-Experienced.

(Q.6:17-18)

God fixes the term of the life of creatures as well as the term of nations; he provides the basis for all life. God alone gives life and death. ${ }^{43}$ God is the holder of man's destiny and the latter cannot escape divine scrutiny:

Thus does God lead astray whom He wills,

And guides whom He wills.

None knows the troops of your Lord save He,

And it is nothing but a Reminder to mankind. ${ }^{44}$

\section{Humanity's response}

In the light of all the evidence produced by the Qur'ân humanity is called upon to show gratitude. This obligation to show gratitude appears more forceful when one considers the Arabic term for 'ingratitude', $k u f r$, which also means 'unbelief'. The renowned Islamic thinker Sayyid Abū 'l-A' lā Mawdūdīis describes this condition in the following manner:

Kufr literally means 'to cover' or 'to conceal'. The man who denies God is called Käfir (concealer) because he conceals by his disbelief what is inherent in his nature and embalmed in his own soul - for his nature is instinctively imbued with 'Islam'. His whole body functions in obedience to that instinct. Each and every particle of his

${ }^{42}$ See Q. 35:1.44.

${ }^{43}$ See Q. 32:5-11; cf. 1 Sam. 2:6.

${ }^{44}$ Q. 74:31.

${ }^{45}$ Sayyid Abū 'l-A'lā Mawdūdī (1903-1979) was the founder and head of the Ğamaat-i-Isla$m i$, which is the Indo-Pakistani equivalent of the Muslim Brotherhood. He was one of the most influential and controversial Islamic thinkers of the twentieth century whose writings contributed greatly towards the founding of Pakistan in 1947. His works continue to influence political movements in the Muslim world especially those who adopt a rather isolationist stand against non-Muslims by refusing them equal rights. 
existence - living or lifeless - functions in accordance with 'Islam' and is fulfilling the duty that has been assigned to it. But the vision of this man has been blurred, his intellect has been befogged, and he is unable to see the obvious. His own nature has become concealed from his eyes and he thinks and acts in utter disregard of it. Reality becomes estranged from him and he gropes in the dark. Such is the nature of Kufr. ${ }^{46}$

At the same time, however, the term kufr also means 'demonstrating ingratitude before an act of goodness'. Within this latter context a kāfir would be someone who forgets to show gratitude towards God who has bestowed his goodness in all sorts of ways to humanity:

It is God Who made you, among what He created, the shades, and made the mountains for you places wherein to hide, and made for you shirts to protect you from the heat, and other shirts to protect you in battle. Thus does He complete His bounty upon you; perhaps you will submit to Him.

If they turn away, yours is only to convey a manifest message. They recognize the blessings of God and then repudiate them, and most of them are unbelievers ( $k \bar{a} f i$ rūn).

(Q. 16:81-83)

In acknowledging God as All-Powerful the Muslim perceives God's all-encompassing mercy and compassion (al-Rahmân, al-Rahīm ${ }^{47}$ which is manifest through the entire creation and human history, and is called upon to show gratitude every moment of his/her existence. God is "the most merciful of the merciful;" 48 "the best of the merciful". ${ }^{49}$ This merciful goodness is indicated with regards to certain aspects of nature, everything being ultimately a gift from God:

Among His wonders is the creation of the heavens and the earth, and the diversity of your languages and colours. In these are signs for mankind.

Among His wonders is your sleep by night and day, and your pursuit of His bounty. In these are signs for a people who can hear.

(Q. 30:22-23) $)^{50}$

For commentators of the Qur'ân this and similar passages refer above all to those signs that indicate the omnipotence or the mercy of God expressed in an aura of praise. This perspective is also evidenced in the Wisdom literature of the

\footnotetext{
${ }^{46}$ Sayyid Abū 'l-A' lā Mawdūdī, Towards Understanding Islam, translated and edited by Khurshid Ahmad, Markfield 1982, p. 4.

${ }^{47}$ Both divine attributes are a recurrent Biblical terms. See, for instance, Ps. 86:5.15; 103:8; 145:8.

${ }^{48}$ Q. 12:64.92; 21:83; 7:151.

${ }^{49}$ Q. 23:118.

${ }^{50}$ See also Q. 16:3-18; 27:59-64; 30:17-27. See also Q. 6:95-99; 13:2.8-15.17; 16:65-70; 35:11-14.27-28; 36:33-44.68-73; 55:1-34.
} 
Old Testament wherein are found hymns extolling God as creator whose works attest to his mercy and goodness. ${ }^{51}$

In summary, nature, according to the Qur'ân, is first of all a living environment in which Man learns to become ever more aware of God's presence by way of his attributes as an All-Merciful Master. Man's intellect should lead him to understand the assertions of the Qur'ân on this point and to admit the evidence. For Man the act of knowing is first and foremost acknowledging the attributes and commandments of God in order to abide by them.

These signs are not only invitations to stand in awe and wonder at the magnificence of the cosmos but also to reflect on the fact that the whole of nature was created for Man and that Man must demonstrate gratitude by acknowledging the oneness of and submitting to God, that is to say, by his Isläm.

Thus all natural phenomena lead to God. The entire cosmos is a gift of God. Natural phenomena have their proper value but, in the final analysis, they remain divine gifts. Before God, the Giver of all things, everything pales into insignificance.

\section{Tożsamość i cel człowieka według Koranu}

\section{Streszczenie}

Joseph Ellul w artykule zatytułowanym Tożsamość i cel człowieka wedtug Koranu odnosi się do tajemnicy stworzenia według świętej księgi muzułmanów. Według Koranu cały wszechświat został stworzony przez Boga. Natura za pośrednictwem stworzenia przypomina człowiekowi o jedyności Boga oraz uczy go niektórych Jego atrybutów. Człowiek, będąc przez Niego stworzony, jest wyposażony w naturalną zdolność do bycia Jego świadkiem i głoszenia jedyności Stworzyciela. Dlatego poprzez kontemplację stworzenia został wezwany do zwrócenia się ku Bogu i podporządkowania się Stworzycielowi, który troszczy się o całe stworzenie. Umieszczony w centrum stworzonej natury, podporządkowanej Bogu, człowiek winien naśladować wszechświat w tym podporządkowaniu. Jest on odpowiedzialny przed Bogiem za swoje działania w świecie. Cała jego aktywność wpisuje się w dzieło stworzenia. W tej perspektywie islam jawi się jako religia naturalna, opierająca się na jedyności Boga, która została wpisana w naturę pierwszego człowieka. Według Koranu Adam już od początku był monoteistą.

\section{Słowa kluczowe}

Bóg, islam, Koran, ludzkość, stworzenie

\section{Keywords}

God, Islam, Qur'an, humanity, creationEllul

${ }^{51}$ See Ps. 104; 136:1-9; Sir. 43. 